\title{
The Role of Balanced Fertilization on the Reduction of Phytic Acid to Zinc Molar Ratio (PA/ Zn) in the Irrigated and Rainfed Wheat Fields on the Calcareous Soils of Iran
}

\author{
Malakouti MJ ${ }^{1 *}$, Bybordi $\mathrm{A}^{2}$, Bahrami $\mathrm{A}^{3}$ and \\ Asbaghian Namini SKh ${ }^{3 *}$ \\ ${ }^{1}$ Professor, Department of Soil Science, Tarbiat Modares \\ University, Tehran, Iran \\ ${ }^{2}$ Researcher, East Azarbaijan Province, Iran \\ ${ }^{3}$ Graduate Students, Department of Soil Science, Tarbiat \\ Modares University, Tehran, Iran \\ *Corresponding author: Malakouti MJ , Professor, \\ Department of Soil Science, Tarbiat Modares University, \\ Tehran, Iran
}

Asbaghian Namini SKh, Graduate Students, Department of Soil Science, Tarbiat Modares University, Tehran, Iran

Received: November 30, 2021; Accepted: December 29, 2021; Published: J anuary 05, 2022

\begin{abstract}
One of the most important quality factors in the wheat grain, which directly affects the quality of the bread, is the molar ratio of phytic acid to zinc (PA/ $\mathrm{Zn}$ ) index. In order to evaluate the role of balanced fertilization on increasing the yield, quality, and reducing PA/Zn in wheat grain (Triticum aestivum L.), the first experiment was implemented with two fertilizer treatments (Farmer's conventional fertilization practice, i.e. NP-fertilizers) and the optimum use of fertilizers (fertilization was on the basis of soil test results) in three different irrigated farms in Mianeh, East Azarbaijan province and the second experiment was carried out in 10 different dryland farms on the outskirts of the Khodabandeh, Zanjan Province in 2010-2011 growing season with an average of $380 \mathrm{~mm}$ annual rainfall. This experiment had three treatments, i.e. $T_{1}=$ Control (no fertilizer); $\mathrm{T}_{2}=$ Farmer's conventional fertilization practice (NP-fertilizers), and $\mathrm{T}_{3}=$ Fertilization based on soil test values (Optimum use of fertilizers) in four replications with a randomized complete block design. The wheat cultivar in the irrigated farms was Alvand and in the rainfed farms was Azar-2. Protein, phytic acid, phosphorus $(\mathrm{P})$, potassium $(\mathrm{K})$, magnesium $(\mathrm{Mg})$, iron $(\mathrm{Fe})$, manganese $(\mathrm{Mn})$, copper $(\mathrm{Cu})$, and Zinc $(\mathrm{Zn})$ in wheat grains were analyzed according to the standard methods. The collected data were analyzed by using a t-test and SAS Software. The results revealed that in the irrigated wheat fields, the optimal use of fertilizers increased the grain yield up to 27 percent, protein content, all micronutrients especially $\mathrm{Zn}$ significantly, but it decreased $\mathrm{PA} / \mathrm{Zn}$ molar ratio significantly in comparison to Farmer's conventional fertilization practice. While phytic acid concentration in the control plots was 8.70, it decreased up to $7.41 \mathrm{gkg}^{-1}$, Zn concentration was increased from 29 to $43 \mathrm{mgkg}^{-1}$ and subsequently, PA/Zn molar ratio was reduced from 30 to 17 . The statistical analysis showed a significant difference for phytic acid, $\mathrm{Zn}$, and PA/Zn molar ratio in all wheat farms in the second experiment, the results demonstrated that while the average grain yield in $T_{1}$ was $975 \mathrm{kgha}^{-1}$, it has increased up to $1401 \mathrm{kgha}^{-1}$ in $\mathrm{T}_{2}$ and over $1628 \mathrm{kgha}^{-1}$, respectively. The average yield increase was significant at the $5 \%$ level despite the existing drought situation in the fall of 2010. The mean concentration of $P$ and $Z n$ in wheat grains in the control plots were 0.26 percent and $21 \mathrm{mgkg}^{-1}$, in Farmer's conventional fertilization practice were 0.24 percent and $25 \mathrm{mgkg}^{-1}$ and in the fertilization based on soil test values were 0.21 percent and $30 \mathrm{mgkg}^{-1}$, respectively and they were significant in the $5 \%$ level. While PA/Zn in the control plots was 29 , it has been decreased to 22 in $\mathrm{T}_{2}$ and to 15 in $\mathrm{T}_{3}$ plots, respectively. Comparison between PA/Zn molar ratios revealed that due to the existing water during the growing season in the irrigated fields, the availability of all nutrients including $\mathrm{Zn}$ was slightly higher, but in drylands, the amount and distribution of rainfall is much important and it is clear that by increasing the amount and distribution of rainfall during the growing season, more grain yield and lower PA/Zn molar ratio is expected. It is obvious that these variations are widely dependent on climate change, cultivars, and management factors. This project is recommended to be continued at least in the wheat-grown provinces all over the Iran.
\end{abstract}

Keywords: Wheat (Triticum aestivum L.); Irrigated and rainfed fields; Phytic acid; Zinc (Zn); Phytic acid to Zinc (PA/Zn) molar ratio index

\section{Introduction}

As Mayer [1] said; the health comes from the farm, not the pharmacy is an important issue which heading us towards a balanced fertilization. As we know one of the basic principles of sustainable production is to improve soil quality in terms of fertility and return nutrients absorbed by plants to the soil. Nutrient's uptake ratio from soil for most crops is mainly in the form of $100(\mathrm{~N})-15(\mathrm{P})$ -
Ann Agric Crop Sci - Volume 7 Issue 1 - 2022 ISSN: 2573-3583 | www.austinpublishinggroup.com Malakouti et al. (C) All rights are reserved
Citation: Malakouti MJ, Bybordi A, Bahrami A and Asbaghian Namini SKh. The Role of Balanced Fertilization on the Reduction of Phytic Acid to Zinc Molar Ratio (PA/Zn) in the Irrigated and Rainfed Wheat Fields on the Calcareous Soils of Iran. Ann Agric Crop Sci. 2022; 7(1): 1104. 
$80(\mathrm{~K})-30(\mathrm{~S})-30(\mathrm{Ca})-15(\mathrm{Mg})-0.50(\mathrm{Fe})-0.30(\mathrm{Mn})-0.20(\mathrm{Zn})-0.10(\mathrm{Cu})-$ $0.05(\mathrm{~B})$. Therefore, balanced fertilization in farms is essential to achieve this goal [2].

The concept of balanced fertilization (application of fertilizers based on the soil test and leaf analysis values) has been extensively studied in recent years in relation to new outlooks in Soil Fertility and Plant Nutrition, which include the topic of soil and human health in directing soil nutrient management concerns more towards human safety and health rather than merely yield increases, so that the topic of balanced fertilization for human health is considered to be one of the primary objectives for controlling malnutrition in human populations; most importantly by emphasizing iron (Fe), zinc $(\mathrm{Zn})$ and boron (B) nutrients in our agricultural products. However, a more logical approach would be to enrich the crops in cultivated soils with balanced fertilization so that everyone gets the required amount of this essential nutrient in their diets by consuming enriched wholewheat bread and brown rice as well as other enriched products.

According to our findings, fertilizers account sometimes up to half or more in soils depleted of plant nutrients or balanced fertilization is taking into practice In situations where the role of balanced fertilization especially micronutrients in the health of consumers is in question, then the loss in terms of human health will not be countable. But according to the latest information, more than $85 \%$ of fertilizers used in Iran are allocated to urea and triple superphosphate. This is practically an alarm for the production of healthy agricultural products and a threat to the country's food security. However, scientific management of the production and consumption of fertilizers is inevitable in order to improve society's health by reforming the structure of production, optimal use of fertilizers, and production of healthy agricultural products [3].

Continuous unbalanced use of fertilizers, in addition to being a serious threat to soil health, reduces the quality of agricultural products. Since the mid-2000s, the optimal use of fertilizers has not been observed due to various reasons. During this period, except for subsidized urea and superphosphate, no other fertilizer was provided to agricultural producers, and even in 2011, in addition to this disorder, the total amount of fertilizer used in the country, which was supposed to exceed four million tons a year, was reduced to less than half in practice. Obviously, the yield of agricultural products, especially wheat, was greatly reduced [4].

Excessive consumption of phosphorus fertilizers increases the concentration of phytic acid, which is the form of phosphorus storage in the grain. $75 \%$ of total phosphorus in cereals is in the form of phytic acid. Its chemical name is cyclohexane hexyle hexametaphosphate, its molecular formula is $\mathrm{C}_{6} \mathrm{H}_{18} \mathrm{O}_{24} \mathrm{P}_{6}$ with a molecular weight of 660 . Phytic acid has the ability to form complexes with nutrients and causes the formation of complexes with mineral cations such as calcium $(\mathrm{Ca})$, magnesium $(\mathrm{Mg})$, zinc $(\mathrm{Zn})$ and iron $(\mathrm{Fe})$ and hence, prevents the absorption of these elements in the gastrointestinal tract, and ultimately causes their excretion from the body and as a result the lack of these elements in human's body [2].

\section{Phytic acid $\left(\mathrm{C}_{6} \mathrm{H}_{18} \mathrm{O}_{24} \mathrm{P}_{6}\right)+$ Cations $(\mathrm{Ca}, \mathrm{Mg}, \mathrm{Zn}, \mathrm{Cu}, \mathrm{Fe}) \rightarrow$ Phytates}

It is obvious that by using excess amounts of P-fertilizers in the absence of $\mathrm{Zn}$-fertilizers in wheat fields will increase the molar ratio of phytic acid to zinc (PA/Zn) in wheat grains. The molar ratio of phytic acid to zinc $(\mathrm{PA} / \mathrm{Zn})$ is very important in terms of the absorption of mineral elements, especially zinc in the digestive system. It should be below 25 in wheat grains [3].

(PA/Zn) Molar ratio index: One of the important quality indicators in wheat grain that is directly effective in improving the quality of bread and the feasibility of consuming fortified whole wheat bread is the molar ratio of phytic acid to zinc (PA/Zn) and it is necessary for this index to be lower in wheat grains. It should be 25 to generalize the consumption of fortified whole wheat bread in Iran as well as in developed countries (Malakouti, 2018). The molar ratio of phytic acid to zinc was first introduced by the World Health Organization (WHO) in 1996 and reported that in order to the elements absorption through food (bread) by the body's digestive system, this index must be less than $25[3,5]$.

Gibson [6] reported that if the value of this index in any food is less than 5 , more than $55 \%$ of the minerals in that food will be absorbed in the body's digestive system, but if the ratio is between 5 and 15 , Only $35 \%$ of the minerals are available and if it is more than 25 , no minerals will be absorbed in the body's digestive system. Unfortunately, this ratio in wheat produced in calcareous soils of Iran, due to the continued unbalanced use of fertilizers, especially the excessive use of phosphate fertilizers and non-use of zinc-containing fertilizers varies up to 60 (although the range of changes depends on soil fertility). Because most (about 70\%) of phytic acid, mineral elements, and vitamins accumulate in wheat bran [3].

Feil and Fossati [7], in a study calculated the correlation coefficient between phytic acid and total phosphorus and reported that in Iranian wheat cultivars the differences between phytic acid to total phosphorus are very different. In an experiment with 6.5 ton $\mathrm{ha}^{-1}$ grain yield, the concentration of phytic acid was $3.02 \mathrm{gkg}^{-1}$ and the total phosphorus concentration of wheat grain was $4.27 \mathrm{gkg}^{-1}$ in the laboratory, thus the ratio of phytic acid to total phosphorus estimated $71 \%$. In another experiment by Erdal et al., [8], the molar ratio of phytic acid to zinc was determined in 78 wheat grain samples in common cultivars in Turkey. The amount of phytic acid ranged from 5.8 to $14.3 \mathrm{gkg}^{-1}$, zinc concentration ranged from 9 to $34 \mathrm{mgkg}$ ${ }^{1}$ and the molar ratio of phytic acid to zinc ranged from 138 to 31 . In an experiment, using zinc sulfate levels in two regions in Turkey, they reported that zinc sulfate consumption in Konya increased zinc content in cereals and the molar ratio of phytic acid to zinc decreased from 138 to 61 , and by using zinc sulfate in another point, the average concentration of zinc increased from 26 to $31 \mathrm{mgkg}^{-1}$ and the molar ratio of phytic acid to zinc decreased from 49 to 39 .

The results of 15 years of research in irrigated wheat fields in ten provinces of the country showed that in the samples of wheat produced in farms with farmer's conventional fertilization, the concentration of phytic acid was $10.49 \mathrm{gkg}^{-1}$ and the concentration of zinc was $28 \mathrm{mgkg}^{-1}$. While with the optimal use of fertilizer in the same farms, the concentration of phytic acid decreased to $9.07 \mathrm{gkg}^{-1}$ and the concentration of zinc increased to $35 \mathrm{mgkg}^{-1}$ and the molar ratio of phytic acid to zinc dipped from 37 to 26 . Therefore, with the balanced use of fertilizers, especially zinc sulfate in wheat fields, it was observed that the index ratio of phytic acid to zinc decreased to less than 25 and thus the elements in bread made from whole meal 
flour were absorbed by humans and as a result, there will be no need for bran in the flour preparation process [3]. Malakouti et al., [4] in West Azarbaijan province reported that the average molar ratio of phytic acid to zinc in more than 100 samples of wheat seeds was in the range of 45 to 77 , which is higher than the WHO index. The reasons are mainly related to the lack of optimal use of fertilizers, excessive use of phosphate fertilizers and non-use of fertilizers containing micronutrients, especially zinc sulfate in wheat fields, bran separation in the process of flour production and improper baking of bread. In other words, the amplitude of changes in $(\mathrm{PA} / \mathrm{Zn})$ index in wheat grains produced in calcareous soil fields, in addition to excessive consumption of phosphate fertilizers and non-application of zinccontaining fertilizers $(\mathrm{Zn})$, depends on cultivar and differences in soil fertility due to the organic matter percentage [4].

In recent years, few researches has been done on wheat cultivated lands, mostly related to the years of drought in the country that the yield of rainfed crops has been strongly affected by moisture stress and as a result has overshadowed the positive effect of micronutrient fertilizers. According to the results of studies, it was concluded that the use of zinc sulfate in combination with the balanced use of phosphate and nitrogen fertilizers increased the yield and concentration of zinc in rain-fed wheat grains [4].

According to several researchers, including [2,9], the enrichment process is a valuable solution and is the cheapest and the best idea to compensate micronutrient deficiencies in calcareous soils. In fertile lands, most of the micronutrients in wheatgrass are concentrated in bran and do not normally enter the diet, so it is recommended that whole-grain breads with low ratio of phytic acid to zinc (PA/Zn) be used. The studies about conditions under which this quality index in wheat grains produced in the calcareous soils of Iran is reduced to the desired level, requires further study in both irrigated and rainfed wheat fields and this study for this purpose has designed and implemented in different parts of the country since 2000s.

\section{Materials and Methods}

In order to increase yield and decrease the molar ratio of phytic acid to zinc in irrigated and rainfed wheat conditions, first in irrigated fields in the early 2000s, an experiment including two treatments of farmer's conventional fertilization and optimal fertilizer application, in t-test and in Three replications was performed in the arable lands of Miyaneh city of East Azerbaijan province with about $330 \mathrm{~mm}$ of annual rainfall and then another experiment in the 2010-2011 growing season including three fertilizer treatments: control (without fertilization), farmer's conventional fertilization (NP) and balanced fertilization based on soil analysis results was performed in four replications in a randomized complete block design in 10 dryland wheat farms in Khodabandeh, in Zanjan province with an average of $380 \mathrm{~mm}$ of annual rainfall. Before planting, a mixed sample was prepared from each field and after drying the soil and passing it through a $2 \mathrm{~mm}$ sieve, some physical and chemical properties were measured in the laboratory according to the conventional methods of the Soil and Water Research Institute [10].

In irrigated and rainfed wheat fields, phytic acid was measured by the ion-exchange method using a spectrophotometer. $2 \mathrm{gr}$ of the dried and powdered sample was mixed with $\mathrm{HCl}$ at room temperature for three hours. The resulting solution was poured onto the ion exchange column after mixing with $\mathrm{NaOH}$ mixed with EDTA. The ion exchange column was prepared using anion exchange resin. The phytic acid attached to the column was separated from the column with $0.7 \mathrm{M}$ sodium chloride and the phosphorus in its structure was released with nitric acid and sulfuric acid solution. Phosphorus released with ammonium molybdate solution in the presence of sulfonic acid produces a color combination. The adsorption of the resulting solution was measured at a wavelength of $640 \mathrm{~nm}$. Phosphate concentrations of the samples were calculated against phosphorus standards. Considering that $28.2 \%$ of phytic acid is phosphorus, the concentration of phytic acid was obtained from the amount of phosphorus obtained [11]. However, in dryland wheat fields, according to Erdal et al., [8], since the result of laboratory measurement of phytic acid is about $3 \mathrm{gkg}^{-1}$ less than the calculation method, only grain phosphorus was measured and by the calculation method, the amount of phytic acid was determined $\left(3.55^{\star}\right.$ grain phosphorus=Phytic Acid).

In irrigated wheat fields, fertilizers used in the control treatment according to the farmer's conventional method (NP) and in the treatment of optimal fertilizer application, the amount of fertilizers used, including fertilizers containing micronutrients based on the results of soil analysis including iron 15 manganese sulfate 40 and zinc sulfate at a rate of $50 \mathrm{kgha}^{-1}$ were applied before planting and during the growing season, irrigation, weed control and spraying against pests were performed. The irrigated wheat cultivar used in all three farms was Alvand. In the first treatment, no fertilizer was used in the dryland wheat fields. In the second treatment, only nitrogen and phosphate fertilizers were used according to the farmer's conventional fertilization at the rate of $25 \mathrm{kgha}^{-1}$ of urea and $25 \mathrm{kgha}^{-1}$ of triple superphosphate before planting in autumn and $50 \mathrm{kgha}^{-1}$ of urea was used respectively in spring. In the third treatment, based on the results of soil analysis, the amount of $50 \mathrm{kgha}^{-1}$ of urea in autumn before planting and $80 \mathrm{kgha}^{-1}$ of urea in spring was used after planting in all blocks of the third treatment. In all fields, zinc sulfate at a rate of $25 \mathrm{kgha}^{-1}$ was used in all blocks of the third treatment before planting. The amount of phosphate fertilizer according to the results of soil analysis and the needs of each field in all blocks of the third treatment was applied in all farms and before planting, which varied from zero to $75 \mathrm{kgha}^{-1}$. The results of soil analysis in different farms showed that the amount of potassium was high in all farms and thus in the third treatment no potassium fertilizer was used. Fertilization was done by top dressing and wheat planting was done in rows. The rainfed wheat cultivar used was Azar 2 and the amount of seed used was $120 \mathrm{kgha}^{-1}$.

In the harvesting stage, the crop was harvested in irrigated wheat fields in 30 plots of 10 square meters randomly from 4.5 square meters in each of the treatments and the grain and straw yield was determined. Then, from each of the harvested blocks related to each treatment, grain samples were prepared and the amount of nitrogen, phosphorus, potassium, calcium, magnesium, iron, manganese, zinc and phytic acid (PA) were determined in the laboratory. In both experiments, statistical analysis was performed on irrigated wheat using the t-test statistical method and plotting of graphs with Excel software. In dryland wheat, analysis of variance (mean squares) and comparison of means using the software were performed by SAS. 


\section{Results and Discussion}

\section{First experiment (Irrigated wheat fields)}

The results in irrigated wheat fields showed that with optimal fertilizer application, a significant increase in yield (27\%) was observed, phytic acid concentration and phytic acid to zinc molar ratio index significantly decreased compared to the conventional fertilization. The concentration of phytic acid decreased from 8.70 to $7.41 \mathrm{~g} \mathrm{~kg}-1$, the concentration of zinc increased from 29 to $43 \mathrm{mgkg}$ ${ }^{1}$ and the ratio of phytic acid to zinc decreased to 17 (Table 1). In these farms, the average percentage of protein at present, which was $11.01 \%$ in the farmer's conventional fertilization treatment, increased to $14.48 \%$ in the blocks of optimal fertilizer consumption. The mean concentrations of other nutrients such as potassium and magnesium in wheat grain were 0.50 and $0.14 \%$, respectively, iron and manganese 35 and copper $5 \mathrm{mgkg}^{-1}$ [12].

According to Table one, it was found that the effect of the balanced application of fertilizers on the phosphorus concentration in all three farms under test was not significant. The highest amount of zinc in wheat grain was obtained in the treatment of optimal fertilizer application. Protein content in the optimal use of fertilization treatments increased significantly compared to the farmer's conventional fertilization. The highest amount of zinc in wheat grain was in the treatment of optimal fertilizer application. Among the micronutrients, an increase in zinc concentration was observed in all three farms, which was consistent with the results of several researchers, including Malakouti et al., [4]. The highest index of phytic acid to zinc ratio (PA/Zn) was in the control treatment of the third farm and the lowest was in the treatment of optimal fertilizer application of farms No. 1 and 3. Knowing that the availability of micronutrients in food decreases with a molar ratio of phytic acid to more than 25 , so the usability of zinc in wheat produced from calcareous soils in Iran is very low.

\section{Second experiment (Rainfed wheat fields)}

In rainfed wheat fields, the results showed that there was a significant difference between the fertilizer treatments in yield, zinc and phosphorus concentration in grain at the level of $5 \%$. The highest mean grain yield was in the third treatment with $1628 \mathrm{kgha}^{-1}$ compared to the farmer's conventional fertilization which increased by $227 \mathrm{kgha}$ ${ }^{1}(16 \%)$. With the optimal use of fertilizers, in addition to a significant increase in yield, the concentration of phytic acid and the molar ratio of phytic acid to zinc decreased significantly compared to the farmer's conventional fertilization. In other words, the concentration of phytic acid decreased from 9.23 to $8.52 \mathrm{gkg}^{-1}$ and the molar ratio of phytic acid to zinc decreased from 23 to 15 (Table 2). Considering the obtained results, it seems that the use of zinc sulfate and proper management of the use of other fertilizers in rainfed wheat lands will increase the quality of wheat grain. In these farms, the average percentage of protein, while in the farmer's conventional fertilization treatment was $11.77 \%$, this amount in the parts of optimal fertilizer consumption was $13.15 \%$ [13].

Concentration of available zinc $(\mathrm{Zn})$ in calcareous soils for several reasons, including the abundance of calcium carbonate in arable soils, high $\mathrm{pH}$, bicarbonate of irrigation water, low organic matter, drought and salinity stress, persistent unbalanced fertilizer application, excess in consumption of $\mathrm{P}$-fertilizers with no $\mathrm{Zn}$-fertilizers is very low and the molar ratio of phytic acid to zinc is about 60 . While the amount

Table 1: Effect of optimal fertilizer application in increasing yield, protein and reducing molar ratio of phytic acid to zinc in irrigated grain*.

\begin{tabular}{|c|c|c|c|c|c|c|c|}
\hline \multirow{2}{*}{$\begin{array}{c}\text { Qualitative factors } \\
\text { Farm }\end{array}$} & \multirow{2}{*}{ Fertilizer treatment } & \multirow{2}{*}{$\begin{array}{c}\text { Yield } \\
\left(\text { Kg.ha }^{-1}\right)\end{array}$} & \multicolumn{2}{|c|}{ Percentage (\%) } & \multirow{2}{*}{$\begin{array}{c}\text { Mgkg }^{-1} \\
\text { Zinc }\end{array}$} & \multirow{2}{*}{ Phytic Acid (gr. Kg ${ }^{-1}$ ) } & \multirow{2}{*}{ PA/Zn molar ratio } \\
\hline & & & Protein & Phosphorus & & & \\
\hline \multirow{2}{*}{1} & FCF & $3780 \mathrm{~b}$ & $11.54 \mathrm{a}$ & $0.34 \mathrm{a}$ & $30 \mathrm{c}$ & $8.72 \mathrm{a}$ & $29 \mathrm{a}$ \\
\hline & FT & $4710 \mathrm{a}$ & $14.48 \mathrm{~b}$ & $0.29 b$ & $44 \mathrm{ab}$ & $7.14 \mathrm{~b}$ & $16 \mathrm{~b}$ \\
\hline \multirow{2}{*}{2} & FCF & $4510 \mathrm{~b}$ & $10.50 \mathrm{ba}$ & $0.33 \mathrm{~b}$ & $30 \mathrm{c}$ & $8.78 \mathrm{a}$ & $30 \mathrm{a}$ \\
\hline & $\mathrm{FT}$ & $6730 \mathrm{a}$ & $14 \mathrm{~b}$ & $0.31 a b$ & $40 \mathrm{~b}$ & $7.12 \mathrm{~b}$ & $17 \mathrm{~b}$ \\
\hline \multirow{2}{*}{3} & FCF & $6280 \mathrm{~b}$ & $14 \mathrm{a}$ & $0.34 \mathrm{a}$ & $28 \mathrm{c}$ & $8.80 \mathrm{a}$ & $31 \mathrm{a}$ \\
\hline & $\mathrm{FT}$ & 7120 a & $14.90 \mathrm{~b}$ & $0.30 \mathrm{~b}$ & $46 \mathrm{a}$ & $7.15 \mathrm{~b}$ & $15 \mathrm{~b}$ \\
\hline \multirow{2}{*}{ Mean } & FCF & $4857 \mathrm{~b}$ & $11.01 \mathrm{~b}$ & $0.34 \mathrm{a}$ & $29 \mathrm{~b}$ & $8.70 \mathrm{a}$ & $30 \mathrm{a}$ \\
\hline & FT & $6187 \mathrm{a}$ & $14.46 \mathrm{a}$ & $0.30 \mathrm{~b}$ & $43 a$ & $7.41 \mathrm{~b}$ & $16 \mathrm{~b}$ \\
\hline
\end{tabular}

${ }^{*}$ FCF: Farmers conventional fertilization.

${ }^{*} \mathrm{FT}$ : Fertilizer treatment.

*Similar lowercase letters indicate no significant difference at the $1 \%$ level.

Table 2: Effect of optimal fertilizer consumption in increasing yield, protein and decreasing the index of molar ratio of phytic acid to zinc in dryland wheat grain.

\begin{tabular}{|c|c|c|c|}
\hline Treatments & $\mathbf{1}$ & $\mathbf{2}$ & $\mathbf{3}$ \\
\hline Indexes & Blank & Conventional fertilization & Optimal use of fertilizers \\
\hline Yield $\left(\mathrm{kg} . \mathrm{ha}^{-1}\right)$ & 975 & 1401 & 1628 \\
\hline Protein (\%) & 10.75 & 11.77 & 13.16 \\
\hline Zn (mg kg $\left.{ }^{-1}\right)$ & 21 & 25 & 0.41 \\
\hline P (\%) & 0.26 & 0.24 & 30 \\
\hline Phytic Acid (gr. $\left.\mathrm{kg}^{-1}\right)$ & 6.23 & 5.52 & 0.21 \\
\hline PA/Zn & 29 & 22 & 0.006 \\
\hline
\end{tabular}


of zinc that can be used by the DTPA method should be more than $2 \mathrm{mgkg}^{-1}$ of soil, these values in most arable soils of the country do not exceed $0.50 \mathrm{mgkg}^{-1}$. Obviously, wheat that grows in such soils will have very low zinc. In rainfed conditions, low rainfall and inadequate distribution of rain in most parts of the country is a limiting growth factor and the amount of effective rainfall is one of the key factors in increasing production. Optimal rainfall and proper management to maintain moisture and increase soil organic matter in the country's drylands are one of the most important tools for soil conservation, reducing erosion and increasing production in these areas [2].

Comparison of the molar ratio of phytic acid to zinc in irrigated and rainfed wheat showed that this ratio and the effect of balanced and appropriate application of chemical fertilizers in rainfed conditions depend on the proper distribution of rainfall and possibly lack of moisture in optimal fertilizer management conditions in drylands overshadows the plant reaction and undermines the economic efficiency of fertilizer management in the absence of soil moisture.

However, in irrigated conditions, due to the availability of water resources and the use of water in sensitive and phenologically sensitive conditions of wheat growth, the mobility of nutrients including $\mathrm{Zn}$ as well as yield, $\mathrm{Zn}$ concentration and decreasing phytic acid to zinc $(\mathrm{PA} / \mathrm{Zn})$ molar ratio in irrigated grain increases.

\section{Conclusion}

While PA/Zn molar ratio in the wheat grains produced under imbalanced fertilization practice (Farmers' Conventional Fertilization Practice) exceeds 60, application of balanced fertilization, i.e. application of P-fertilizers according to the soil testing and zinc sulfate has decreased PA/Zn molar ratio, significantly. So, the main beneficial effects of practicing balanced fertilization were a) yield increase; b) concentration of mineral nutrients especially $\mathrm{Zn}$ in wheat grains have been increased and c) PA/Zn molar ratio index has been decreased.

In this study we found that on dryland wheat with irrigated wheat, if there is sufficient moisture in the drylands, is comparable in terms of reduction percentage of molar ratio of phytic acid to zinc and balanced and optimal use of chemical fertilizers in these conditions, increase sustainable fertility and solve nutritional problems in the soil of rainfed. Therefore, considering the above results, it is concluded that the need for a significant reduction in the phytic acid to zinc molar ratio, compliance with the principles of fertilization based on the results of soil analysis and otherwise the principles of optimal fertilizer based on nutrient uptake in all soils of irrigated and rainfed wheat farms, so that by reducing this important quality index, through the production of fortified wheat, the consumption of wholemeal bread in the community will be generalized and thus the community health will be improved.

At the end it can be suggested that a) to generalize the optimal use of fertilizers, fertilizer use in agricultural lands should be based on soil analysis results and the access of agricultural producers to different types of fertilizers should be facilitated, b) it is necessary to reduce the amount of this quality index in the produced wheat grains to less than 25 by practicing balanced fertilization on the based soil analysis results, c) the adage "health comes from the farm, not the pharmacy" came to reality in this study, d) so, by practicing optimal management in fertilizer use and using the enriched agricultural products (healthy agricultural products), the ranking of the human being will be upgraded. At the end, we can say that by practicing balanced fertilization, the country's crop yield and quality as well as society's nutritional status will improve and quality of whole wheat bread will be upgraded, significantly and hence the problem of malnutrition will be solved from our societies.

\section{References}

1. Mayer JE, Wolfgang HP, Beyer P. Biofortifield crops to alleviate micronutrient malnutrition. Current opinion in plant Biology. 2008; 11: 166-170.

2. Malakouti MJ. The role of balanced fertilization on increasing yield and producing healthy agricultural products: Determining the amount, type and time of fertilization to achieve relative self-sufficiency, food security and increase farmer's incomes. $4^{\text {th }}$ publication. Farmer's house, 104, Mobaleghan publication, Tehran, Iran. (In Persian). 2018: 458.

3. Malakuti MJ. Strategies to increase the quality of bread consumed in the country. Journal of Food Science and Technology. 2011; 31: 11-20.

4. Malakouti MJ. Optimal fertilizer consumption is the most effective step in sustainable production of agricultural products and improving the health of the community. Rahboard Magazine. 2013.

5. WHO. Trace element intakes in human nutrition and health. World Health Organization. Geneva, Switzerland. 1996; 361

6. Gibson RS. Inadequate intakes of zinc in developing countries. Practical house-hold strategies to reduce risk of deficiency. 1998

7. Feil B, Fossati D. Phytic acid in triticale grains as affected by cultivar and environment. Crop Science. 1997; 37: 916-921.

8. Erdal I, Yilmaz A, Taban S, Eker S, Torun B, Cakmak I. Phytic acid and phosphorus concentrations in seeds of wheat cultivars grown with and without zinc fertilization. Journal of Plant Nutrition. 2002; 25: 113-127.

9. Tavajjoh M, Karimian N, Olama V. Phytic acid concentration and phytic acid Zinc molar ratio in wheat cultivars and bread flours, Fars Province, Iran Journal of Agricultural Science and Technology. 2011; 13: 743-755.

10. Emami A. Plant's Analysis Methods. Soil and Water Research Institute soil and plant analyses handbook. No. 982. Tehran, Iran. 1996.

11. Bahrampour Gh, Mahboob S, Razavieh V. Phytic Acid to Zinc molar ratio in breads consumed in Tabriz, Iran. Urmia Medical Journal. 2006; 16: 136-142.

12. Bybordi A, Malakouti MJ, Eslamzadeh M. The Role of Optimal Fertilizer Use in Increasing Yield, Improving Quality and Decreasing the Molar Ratio of Phytic Acid to Zinc (PA/Zn) in the Miyaneh, East Azarbayjan province, Iran wheat fields. Journal of Soil and Water: Special Issue of Optimal Fertilizer Use. 2001; 12: 10-16.

13. Bahrami A. Investigating the effect of zinc on increasing yield and decreasing the molar ratio of phytic acid to zinc (PA/Zn) of wheat grain in some dryland wheat fields in Zanjan province, Iran. Master Thesis, Department of Soil Science, Tarbiat Modares University, Tehran, Iran. 2011. 